\title{
Indian tree offers nuclear waste treatment
}

New Delhi. A herbal product claimed to be able to mop up uranium and other longlived isotopes from nuclear waste has been developed by Indian scientists applying modern biological techniques to a traditional method for cleaning dirty water.

The product has been isolated from the seeds of Strychnos potatorum, a tree found growing in forests in the state of Andhra Pradesh. It is also said to be capable of removing cadmium, mercury and other toxic heavy metals from factory effluent, and to have potential uses in the mining industry, as it can bind to metals such as gold, silver, cobalt, copper and nickel.

For centuries, indigenous people living in the state have been aware of the seeds' ability to precipitate fine particles into larger masses. Even today the powdered seed is used to transform muddy water in streams and wells into clean drinking water.

Realizing that the seeds of the littleknown tree, which grows only in India, Burma and Sri Lanka, might have many industrial applications, the state's Girijan
Cooperative Corporation (GCC) hired a team of scientists two years ago to conduct research on their remarkable properties.

"All that we did was to isolate the substance responsible for the property which the tribals already knew", says Durga Prasad, a biochemist and leader of the research team. The product does not yet have a name; the scientists refer to it simply as a bioflocculant.

According to Prasad, the ease with which the substance binds with a variety of metals is dependent on the $\mathrm{pH}$ of the reaction medium. The binding efficiency has been found to be high; one mole of bioflocculant can apparently absorb between 20 and 25 moles of metal. Prasad says that the ability of the seeds to bind metals appears to result from the presence of certain proteins.

This has been confirmed by Clement Furlong, professor of biochemistry at the University of Washington in Seattle, who is carrying out a joint research project with GCC to study the substance's properties.

"These proteins are apparently unique", says Furlong. He said his collaboration has

\section{S. Korea pauses on science reforms}

Seoul. President Young-Sam Kim of South Korea has called a temporary halt to negotiations overa planned reorganization of the countries' science-related ministries because of disagreement between them about the form that the reorganization should take.

South Korea has changed dramatically over the past three decades from a poor agricultural society to an industrialized nation with a developed research infrastructure. But the growing involvement of different ministries and agencies in research has put a strain on the distribution of responsibilities, and made reorganization necessary.

Shortly after coming to power earlier this year, Kim promised such a reorganization, and it had been expected that his plans for achieving it would be presented to parliament this month (see Nature 364, 384; 1993). But this move has now been postponed to allow further time for discussion.

Some of the more powerful ministries in Seoul, such as those of trade and industry and communications, want to reduce the powers of the relatively young Ministry of Science and Technology (MOST). They would like to see MOST take on more of a purely coordinating role as they themselves become increasingly involved in supporting research and development.

These ministries would, for example, like greater responsibility for the budgets of individual research institutes. A step in this direction was the recent transfer to the Electronics and Telecommunications Research Institute, previously funded by MOST, to the ministry of communications.
Others, however, would prefer to see a strengthening of the Presidential Council on Science and Technology, whose members include the Minister of Science and Technology. This could also lead to a stronger role for MOST, and in particular its Science and Technology Policy Institute.

And there are some who argue that the main need is to boost the priority given to science and technology by the Economic Planning Board (EPB), Korea's equivalent to Japan's powerful Ministry of Finance. This could, for example, be done through the creation of a new section in the EPB.

Ever since the proposed reorganization was announced, different ministries and agencies have been giving their own, often opposing, views to the president. This process has now been halted to give the president and his advisers more time to consider the implications of the different options.

As part of this process, the presidential council last week held the first of a series of meetings with foreign science policy specialists to see what can be learnt from the experiences of other advanced industrialized nations, in particular Japan.

Other advisory bodies, such as a restructuring committee and economic advisers to the president, are also expected to present their views on what changes should be introduced. And the final plan could contain elements of all the various alternatives now being put forward. But there is still uncertainty over how much time should be spent on building consensus before changes are put into effect.

David Swinbanks two aims: to purify the proteins still further, in order to improve their specificity and metal binding ability; and to clone the genes coding for the proteins, so that they can be manufactured using the techniques of biotechnology.

The herbal product has a very high affinity for uranium, and might therefore be used for removing traces of this metal from reactor effluent, a characteristic that has already attracted the attention of the International Atomic Energy Agency (IAEA).

K. Mahadey Rao, a senior official of the IAEA, says that the agency is exploring its possible use in the manufacture of cobalt-free steel for the nuclear industry. Cobalt becomes radioactive after it has been ir-

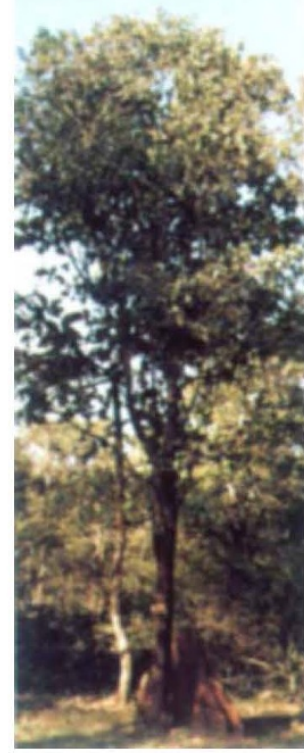

Strychnos potatorum: its seeds can bind to toxic metals. radiated by neutrons, but there is no way of making steel free of contamination by cobalt.

According to Rao, the ability of the bioflocculant to bind with actinides means that another possible use is in nuclear waste disposal, particularly because the selective removal of actinides makes the remaining nuclear waste easier to handle.

Metal binding biochemicals are not new. But Prasad claims this is the first time that a biological substance has been isolated from a plant capable of binding with a wide range of metals.

K. S. Jayaraman

India appears to have averted the prospect of a US ban on the reprocessing of spent fuel from the US-built nuclear power plant at Tarapur by provisionally agreeing with the International Atomic Energy Agency (IAEA) to continue applying IAEA safeguards to Tarapur, to the spent fuel, and to its reprocessing.

The United States has supplied Tarapur, north of Bombay, with enriched uranium fuel under a 30-year-old agreement that expires this week. The United States has said it will not allow the country to begin reprocessing unless it signs the nuclear NonProliferation Treaty.

An interim agreement on Tarapur was announced last week in Bombay by Hans Blix, the director general of IAEA. A full agreement, which would cover reprocessing, is due to be negotiated in December. 